\title{
Morfometri Portunus pelagicus, Linnaeus, 1758 (Malacostraca : Portunidae) dari Perairan Jobokuto, Jepara
}

\author{
Yuftah Rizkasumarta*, Adi Santoso, Endang Sri Susilo \\ Departemen IImu Kelautan, Fakultas Perikanan dan IImu Kelautan, Universitas Diponegoro \\ JI. Prof. H. Soedarto S.H, Tembalang,Semarang, Jawa Tengah 50275 Indonesia \\ ${ }^{*}$ Corresponding author, e-mail:yuftahrizkasumarta@gmail.com
}

\begin{abstract}
ABSTRAK : Rajungan (Portunus pelagicus) memiliki nilai ekonomi tinggi, tetapi keberadaannya secara alami berhadapan dengan tingkat penangkapan yang semakin meningkat. Pesatnya perkembangan perusahaan eksportir rajungan dengan bahan baku yang bersumber dari hasil tangkapan nelayan, mengakibatkan sangat banyaknya nelayan yang melakukan penangkapan. Penangkapan rajungan dengan frekuensi tinggi dan terus-menerus tanpa memperhatikan ukuran serta kondisi rajungan, berpotensi mengurangi stok rajungan di perairan. Penelitian ini bertujuan untuk mengetahui distribusi ukuran, serta hubungan lebar karapas dengan berat rajungan yang didaratkan dari perairan Jobokuto, Jepara. Hasil dari penelitian ini menunjukkan, dari 1500 rajungan yang diamati diketahui bahwa distribusi lebar karapas berkisar 10,50-11,30 cm, dan berat berkisar 75-104 gram. Hubungan lebar karapas dengan berat rajungan menghasilkan nilai $b$ sebesar 1,68 untuk rajungan jantan dan 2,80 untuk rajungan betina, sehingga baik rajungan jantan maupun betina pertumbuhannya bersifat allometrik negatif. Sifat pertumbuhan ini menunjukkan bahwa pertumbuhan lebar karapas lebih cepat dibandingkan pertumbuhan berat rajungan. Persentase penggunaan alat tangkap oleh nelayan rajungan Jepara adalah Bubu (91\%), dan Jaring (9\%).
\end{abstract}

Kata Kunci: Alat Tangkap, Morfometri, Perairan Jobokuto, Portunus pelagicus

\section{Morphometry of Portunus pelagicus, Linnaeus, 1758 (Malacostraca: Portunidae) from Jobokuto Waters, Jepara}

\begin{abstract}
The blue swimming crab (Portunus pelagicus) has a high economic value, but its existence is naturally faced with increasing fishing rates. The rapid development of crab exporters with raw materials sourced from fishermen's catches has resulted in very many fishers making arrests. Catching the crab with high frequency and continuously without regard to the size and condition of the crab has the potential to reduce the crab stock in the waters. This research aimed to determine the size distribution, as well as the relationship of carapace width to the weight of the crab, landed from the seas of Jobokuto, Jepara. The results of this study indicated that of the 1500 crabs observed, the distribution of carapace width ranged from 10.50 to $11.30 \mathrm{~cm}$, and the weight ranged from 75 to 104 grams. The relationship between carapace width and crab weight had a value of $b$ of 1.68 for male crabs and 2.80 for female crabs so that both male and female crabs have negative allometric growth. This growth characteristic showed that carapace width growth is faster than the growth of crab weight. The percentage of fishing gear used by Jepara crab fishermen is Bubu (91\%), and Net (9\%).
\end{abstract}

Keywords: Fishing Gear, Morphometry, Jobokuto Waters, Portunus pelagicus

\section{PENDAHULUAN}

Rajungan merupakan salah satu komoditi perikanan yang bemilai ekonomis tinggi, karena komoditi ini sangat diminati oleh masyarakat, baik dalam negeri maupun luar negeri. Hal ini terlihat dari hasil ekspor rajungan yang mengalami kenaikan setiap tahun. Pasar yang luas dan harga yang tinggi ini menjadi pemicu berkembangnya perikanan rajungan. Hingga saat ini besamya tingkat pemanfaatan dan perdagangan rajungan tidak diimbangi dengan pengetahuan tentang cara melestarikan sumberdaya tersebut. Hal ini dapat berakibat pada terjadinya 
penurunan stok sumberdaya rajungan. Pengetahuan tentang cara melestarikan sumberdaya rajungan dapat meliputi pengetahuan tentang berapa besar tingkat rekruitmen, berapa ukuran yang layak tangkap, dan bagaimana karakteristik habitatnya. Melalui penelitian tersebut dapat disusun suatu pengelolaan perikanan yang tidak hanya berorientasi pada produksi tapi juga pada bioekologis rajungan. Lokasi penelitian yang dipilih di daerah Jobokuto, Jepara. Karena rajungan yang rajungan yang didaratkan di daerah Jobokuto, Jepara merupakan pengolahan rajungan terbesar di daerah Jepara, sehingga data yang didapat dapat digunakan sebagai kepentingan akademisi maupun keperluan instansi.

Manfaat penelitian ini adalah mengetahui ukuran rajungan, karakteristik habitat rajungan, pola pertumbuhan rajungan, sebaran lebar karapas dan berat rajungan merupakan informasi dasar yang sangat penting untuk melihat karakter morfometrik rajungan dari perairan Jobokuto, Jepara. Karakter morfometrik rajungan jantan dan betina yang biasa digunakan untuk membandingkan populasi rajungan antar perairan meliputi lebar karapas dan berat rajungan. Penelitian ini bertujuan mengetahui karakter morfometri rajungan di perairan Jobokuto, Jepara sehingga kebijakan serta usaha menstabilkan produksi rajungan dapat dilakukan.

\section{MATERI DAN METODE}

Metode yang digunakan dalam penelitian adalah metode survei yang bersifat deskriptif dengan melakukan pengambilan sampel ke tempat pengepul rajungan Bapak Nahrowi selaku anggota Kelompok Nelayan Berkah Samudra untuk mengumpulkan data mengenai Rajungan (Portunus pelagicus) dengan cara observasi dan wawancara. Metode deskriptif adalah metode penelitian yang dilakukan untuk memperoleh fakta-fakta dari gejala-gejala yang ada dan mencari keterangan secara faktual dari suatu kelompok ataupun suatu daerah kemudian melakukan analisa lebih lanjut mengenai kebenaran tersebut. Setelah pengumpulan data selesai dilakukan analisis data dan membuat kesimpulan tentang kondisi biologi Rajungan. Sampel rajungan diambil sebesar $10 \%$ dari hasil tangkapan nelayan, hal ini dilakukan untuk memenuhi standard minimal pengambilan sampel secara statistik

Parameter yang diamati meliputi panjang dan lebar karapas, serta jenis kelamin. Panjang rajungan diukur dari anterior (tempat mata berada) ke arah posterior (tempat abdomen berada) ( $A$ - B) sedangkan lebarnya diukur dari duri lateral terpanjang yang berada di sisi - sisi tubuhnya (C D) dapat dilihat pada Gambar 1. Penentuan jenis kelamin dibutuhkan untuk melakukan analisis seks rasio dan pola reproduksi rajungan serta distribusi temporal maupun spasial jenis kelamin. Dilakukan pengambilan sampel air untuk mengamati kualitas air yang meliputi salinitas, suhu, DO. Setelah melakukan penangkapan rajungan, dilakukan pengukuran lebar karapas, berat total, pemisahan dan penghitungan rasio jenis kelamin. Presentase penggunaan alat tangkap nelayan rajungan di Jepara bertujuan untuk mengetahui variasi alat tangkap rajungan yang digunakan oleh nelayan perairan Jobokuto, Jepara.

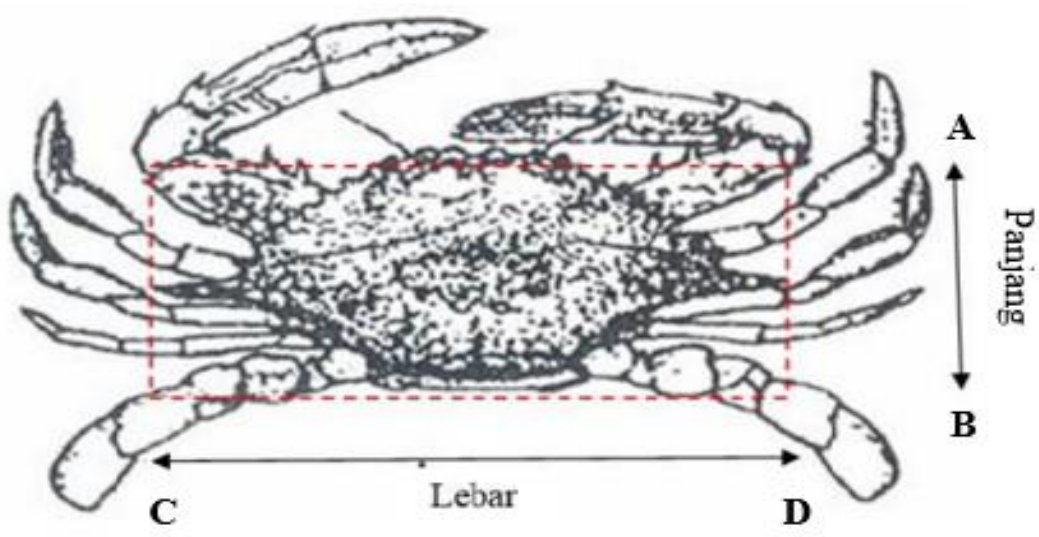

Gambar 1. Sistem pengukuran panjang dan lebar karapas rajungan (Santoso, 2016). 
Data tersebut didapatkan berdasarkan pendataan jenis alat nelayan penangkap rajungan di perairan Jobokuto, Jepara. Dilakukan dengan menganalisis frekuensi lebar karapas rajungan dengan menggunakan metode Bhattacharya. Sebaran frekuensi lebar karapas dikelompokkan ke dalam beberapa kelompok umur yang diasumsikan menyebar normal, masing masing kemudian dicirikan dengan nilai rata rata dan simpangan baku (Asnidar, 2013). Apabila indeks separasi kurang dari dua (<2) maka tidak mungkin dilakukan pemisahan kelompok ukuran karena akan terjadi tumpang tindih dengan kedua kelompok ukuran tersebut, dengan rumus (Sparre, 1999). Analisis pertumbuhan lebar dan berat bertujuan untuk mengetahui pola pertumbuhan rajungan di alam. Mencari hubungan antara lebar dan berat total digunakan persamaan sebagai berikut (Effendie, 2002):

Dengan pendekatan regresi linier maka hubungan kedua parameter tersebut dapat dilihat. Nilai $b$ digunakan untuk menduga laju pertumbuhan kedua parameter yang dianalisis. Hipotesis yang digunakan adalah : Jika nilai $b=3$ maka disebut pola pertumbuhan isometrik (pola pertumbuhan panjang sama dengan pertumbuhan berat). Jika nilai $b \neq 3$ maka disebut allometrik yaitu : Jika $b>3$ disebut pola pertumbuhan allometrik positif (pertumbuhan berat lebih cepat dibandingkan pertumbuhan lebar karapas). Jika $b<3$ disebut pola pertumbuhan allometrik negatif (pertumbuhan lebar karapas lebih cepat dibandingkan pertumbuhan berat).

\section{HASIL DAN PEMBAHASAN}

Presentase penggunaan alat tangkap nelayan rajungan di perairan Jepara sebagian besar adalah Bubu (91\%), dan Jaring (9\%). Data tersebut didapatkan berdasarkan pendataan jenis alat nelayan penangkap rajungan di perairan Jepara. Alat tangkap yang digunakan oleh para nelayan di perairan Jepara bervariasi. Namun, alat tangkap yang lebih dominan digunakan oleh para nelayan untuk menangkap rajungan di perairan Jepara adalah bubu. Hal ini sesuai dengan pendapat ahli yang mengatakan bahwa biota perairan yang umumnya dijadikan target penangkapan bubu adalah ikan dasar seperti udang, kepiting, keong, belut laut, cumi-cumi atau gurita baik yang hidup di perairan pantai, lepas pantai maupun yang hidup di perairan laut dalam (Ubaidillah, 2014). Permasalahan yang terdapat di perairan Jepara secara keseluruhan adalah tidak adanya regulasi dan konsistensi aturan hukum. Adanya pemberlakuan penggunaan arad oleh Menteri Kelautan dan Perikanan sehingga membuat sebagian besar nelayan Jepara pada tahun 2017 menggunakan alat tangkap arad lagi. Terkait alat tangkap yang dilarang pemerintah, keberadaan alat lain seperti Arad, Bolga dan Dogol, masih ada yang menggunakannya namun masih menjadi polemik di masyarakat. Hal ini diduga menjadi awal mula permasalahan alat tangkap bubu dan arad yang menjadi konflik di perairan Jepara dan sekitarnya, karena nelayan arad tidak mematuhi regulasi wilayah penangkapan yang seharusnya. Konflik nelayan arad dan bubu di perairan ini membuat sebagian besar nelayan bubu mengalami kerugian berupa hilangnya alat tangkap yang diambil oleh nelayan arad saat bubu yang dipasang terkena jaring arad. Regulasi yang diberlakukan oleh Pemerintah tentang zonasi atau wilayah penangkapan sebenarnya sudah di atur dengan baik, akan tetapi di perairan Jepara sebagian nelayan arad tidak mematuhi peraturan tersebut. Wilayah yang sudah diatur menjadi tidak terkontrol dengan baik, dan menimbulkan berbagai permasalahan di masyarakat.

Jobokuto merupakan salah satu desa pemasok rajungan di Kabupaten Jepara. Alat tangkap yang digunakan oleh nelayan rajungan di perairan Jepara adalah bubu atau jaring. Nelayan rajungan menggunakan armada perahu motor tempel yang berukuran 2-5 GT dengan mesin penggerak berkekuatan 10-16 PK dengan lama trip 1 hari (one day fishing).Berdasarkan wawancara dengan Bapak Nahrowi, dikatakan bahwa banyaknya jumlah desa yang menjual tangkapan rajungan ke daerah Jobokuto, Bapak Nahrowi, dikarenakan Bapak Nahrowi menyebar sejumlah pedagang kecil ke berbagai Desa untuk mengambil rajungan dari kapal nelayan yang selanjutnya akan disetorkan ke perebusan Bapak Nahrowi.

Berdasarkan wawancara dengan bapak Mustain selaku ketua kelompok Berkah Samudra. Data yang diambil ditempat pengolahan rajungan Bapak Nahrowi ini mewakili $70 \%$ data produksi rajungan di perairan Jepara. Pengolahan rajungan di Jepara juga terdapat di daerah demaan dan Pesajen, namun pemasok rajungan tidak sebanyak di tempat perebusan Bapak Nahrowi. 
Rajungan yang mendarat ditempat pengolahan bapak Nahrowi ini merupakan pengolahan rajungan terbesar di daerah Jepara, sehingga data yang didapat dapat digunakan sebagai kepentingan akademisi maupun keperluan instansi.

Pengepul terbesar di Kabupaten Jepara adalah tempat pengepul rajungan milik Bapak Nahrowi. Pengepul Nelayan penangkap rajungan di perairan Jepara berasal dari 12 Desa di Kabupaten Jepara antara lain Bandengan, Bringin, Bulu, Demaan, Jobokuto, Kauman, Mlonggo, Ngemplak, Pesajen, Semat, Teluk Awur dan Ujung Batu.. Nelayan rajungan menjual hasil tangkapan ke pengepul besar di Jobokuto (Bapak Nahrowi). Keseluruhan desa tersebut menggunakan alat tangkap Bubu dan Jaring untuk menangkap rajungan. Hasil penelitian menunjukkan bahwa rajungan yang tertangkap dan menjadi sampel penelitian ini dibedakan berdasarkan jenis kelamin. Dari 1500 ekor rajungan, terdapat 727 ekor jantan dan 773 ekor rajungan betina. Hasil pengukuran rata-rata lebar karapas rajungan jantan berkisar 10,92 cm sedangkan rajungan betina memiliki ukuran yang lebih besar berkisar $11,10 \mathrm{~cm}$. Lebar karapas maksimum pada rajungan jantan adalah $9 \mathrm{~cm}$, sedangkan betina $16,5 \mathrm{~cm}$. Lebar karapas minimum pada jantan $3 \mathrm{~cm}$, sedangkan betina sebesar $6,5 \mathrm{~cm}$.

Jika dilihat dari berat tubuhnya, rajungan jantan memiliki berat tubuh rata-rata sebesar 98,83 gram, sedangkan rajungan betina memiliki berat yang lebih ringan sebesar 95,08 gram. Berat maksimum untuk rajungan jantan sebesar 375 gram, sedangkan rajungan betina sebesar 330 gram. Selanjutnya, berat minimum rajungan jantan sebesar 15 gram dan rajungan betina sebesar 20 gram. Besar kecilnya ukuran rajungan yang tertangkap menggambarkan baik buruknya kualitas dan kuantitas tangkapan yang dilakukan nelayan di perairan Jepara. Budiaryani (2007) menyatakan bahwa ukuran rajungan berdasarkan lebar karapasnya dikelompokkan menjadi tiga fase, yaitu $<6 \mathrm{~cm}$ merupakan fase juvenil, $6-12 \mathrm{~cm}$ merupakan rajungan muda, dan $>12 \mathrm{~cm}$ merupakan fase dewasa.

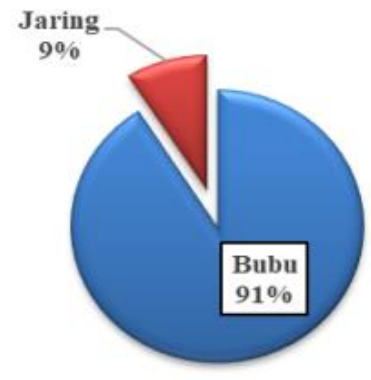

Bubu Jaring

Gambar 2. Presentase penggunaan alat tangkap nelayan rajungan

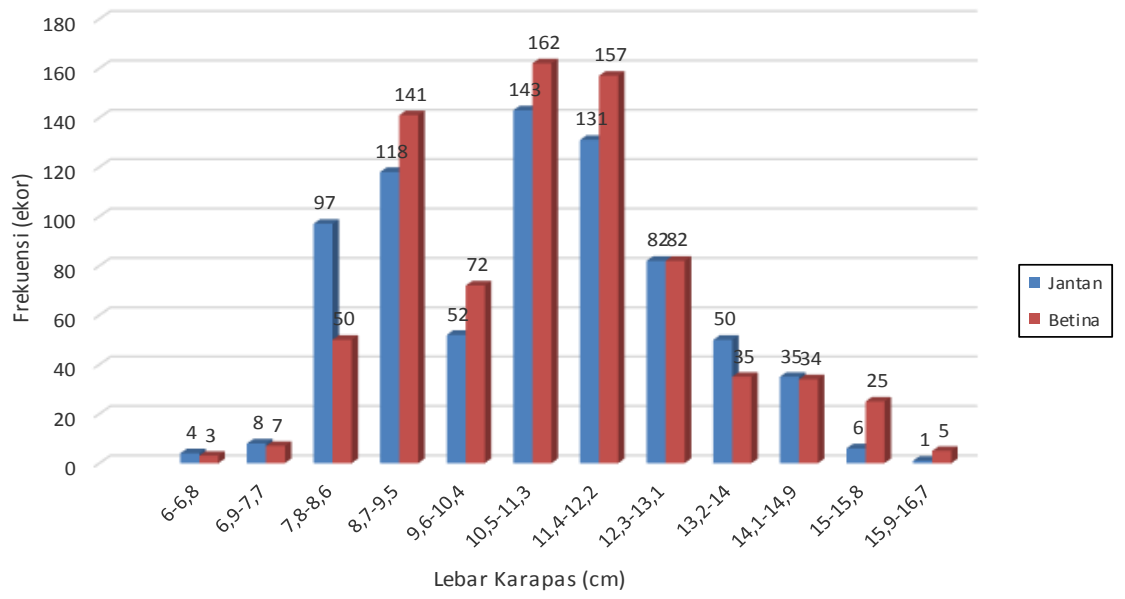

Gambar 3. Sebaran frekuensi lebar karapas $(\mathrm{cm})$ rajungan (Portunus pelagicus) selama penelitian di perairan Jepara 
Berdasarkan sebaran lebar karapasnya, diketahui bahwa rajungan jantan dan betina hasil penangkapan di perairan Jepara memiliki puncak frekuensi tertinggi berada pada ukuran 10,5-11,3 $\mathrm{cm}$. Hasil ini lebih besar jika dibandingkan dengan penangkapan rajungan di daerah Lampung Timur yang menunjukkan nilai frekuensi puncak berkisar 5,3-6,3 cm (Kurnia et al., 2014). Namun rajungan hasil penangkapan di perairan Jepara memiliki ukuran lebih rendah jika dibandingkan dengan rajungan hasil penangkapan di perairan Pulau Lancang Kepulauan Seribu yang memiliki ukuran 13,0-15,3 cm. Jika dilihat berdasarkan ukuran lebar karapas rajungan hasil penangkapan nelayan dari perairan Jepara masih tergolong kedalam kelompok dewasa atau keadaan dimana rajungan boleh ditangkap. Rajungan jantan dan betina di perairan Jepara memiliki puncak frekuensi pada berat 75 - 104 gram. Hasil ini lebih besar jika dibandingkan dengan di perairan Betahwalang, Demak yang mempunyai puncak frekuensi pada berat 26,1 - 48 gram (Apriliyanto dan Yulianto, 2014).

Perbedaan ukuran dapat dipengaruhi oleh beberapa faktor. Bervariasinya ukuran rajungan menurut Afifah (2017) dapat disebabkan oleh faktor jenis kelamin, umur, parasit dan penyakit, kualitas perairan, ketersediaan makanan, perbedaan musim, hilangnya anggota tubuh, preferensi rajungan terhadap habitatnya, dan tingkat intensitas penangkapan. Dalam penelitian Jaya dan Sondita (2012) menyatakan bahwa semakin jauh dari pantai, rata-rata lebar karapas rajungan meningkat dan konstan pada jarak tertentu. Semakin jauh dari pantai maka ukuran rajungan semakin besar. Sehingga diketahui bahwa wilayah tangkapan menjadi salah satu faktor yang mempengaruhi ukuran lebar karapas, selain faktor lingkungan, dan tekanan penangkapan yang berbeda di setiap lokasi penelitian (Ernawati, 2013). Tekanan penangkapan yang tinggi menyebabkan banyak rajungan tertangkap termasuk rajungan dengan ukuran yang masih kecil.

Analisa mengenai hubungan lebar-berat dapat digunakan untuk mempelajari pola pertumbuhan. Lebar karapas pada rajungan dimanfaatkan untuk menjelaskan pertumbuhannya, sedangkan berat dapat dianggap sebagai suatu fungsi dari lebar tersebut. Informasi hubungan panjang/lebar dan berat tubuh individu dalam populasi berguna untuk menduga pola pertumbuhan populasi, khususnya untuk kebutuhan eksploitasi. Hubungan panjang/lebar dan berat dianggap lebih cocok untuk mengevaluasi populasi (Afifah, 2017).

Berdasarkan hasil penelitian, rajungan tangkapan nelayan perairan Jepara, yang didaratkan di Jobokuto memiliki nilai b sebesar 1,68 untuk rajungan jantan, dan 2,80 untuk rajungan betina (Tabel 3). Nilai konstanta $b$ rajungan betina lebih besar dibanding rajungan jantan,

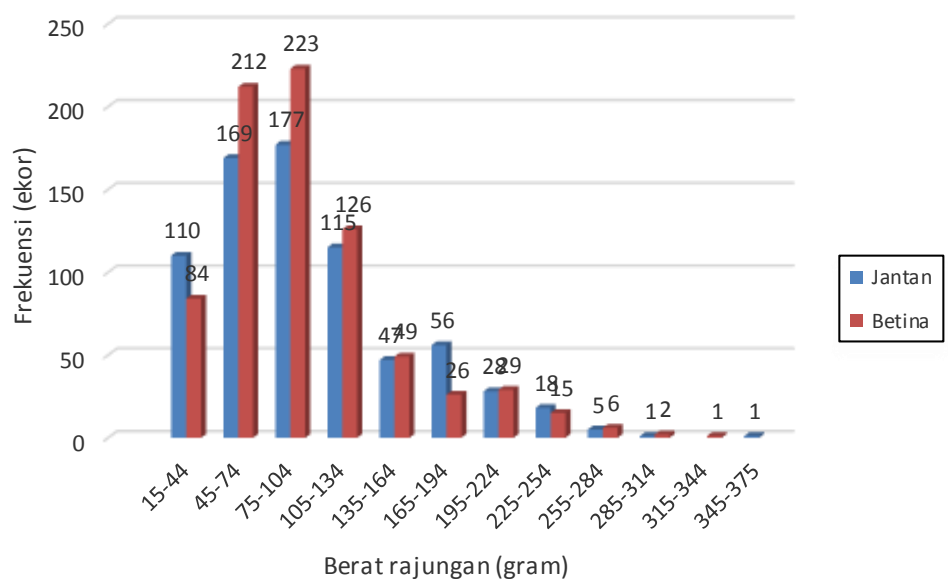

Gambar 4. Distribusi frekuensi berat rajungan (Portunus pelagicus)

Tabel 3. Hubungan lebar karapas dan berat rajungan (Portunus pelagicus) selama penelitian di Jobokuto, Jepara

\begin{tabular}{ccccccc}
\hline \multirow{2}{*}{ Sex } & \multicolumn{5}{c}{ Parameter Hubungan Lebar Karapas dan Berat Tubuh Rajungan } \\
\cline { 2 - 6 } & $\mathrm{n}$ & $\mathrm{a}$ & $\mathrm{b}$ & $\mathrm{SE}$ & $\mathrm{r}$ & Sifat Pertumbuhan \\
\hline Jantan & 727 & 0,7646792 & 1,680502 & 0,197 & 0,60049 & Allometrik Negatif \\
Betina & 773 & $-0,997438$ & 2,807483 & 0,092466 & 0,90792 & Allometrik Negatif \\
\hline
\end{tabular}


mengindikasikan bahwa pada ukuran lebar yang sama rajungan betina lebih berat dibanding rajungan jantan. Secara keseluruhan pertumbuhan rajungan di perairan Jepara baik rajungan jantan maupun betina menunjukkan sifat allometrik negatif dengan $b<3$ (pertumbuhan lebar lebih cepat daripada pertumbuhan beratnya). Pola pertumbuhan rajungan ini sama dengan penelitian di perairan Tangerang oleh Prihatiningsih dan Wagiyo (2009) yang memiliki pola pertumbuhan allometrik negatif (dengan nilai $b=2,86$ untuk jantan, $b=2,69$ untuk betina). Namun berbeda jika dibandingkan dengan hasil penelitian di perairan Teluk Jakarta oleh Sumiono (2011) bersifat allometrik positif (nilai b untuk jantan dan betina masing-masing sebesar 3,089 dan 3,052).

Perbedaan hasil hubungan lebar karapas dan bobot di beberapa perairan dipengaruhi oleh beberapa faktor. Perbedaan nilai $b$ disebabkan oleh faktor luar tubuh seperti perbedaan iklim mikro yang optimum seiring perubahan musim, serta faktor dalam yakni perbedaan jenis kelamin, tingkat kedewasaan, dan kehilangan anggota tubuh (Sunarto, 2012).

Variasi nilai b pada hubungan lebar karapas dan berat tubuh menunjukkan pertumbuhan yang bersifat relatif, artinya dapat berubah berdasarkan perubahan waktu. Apabila terjadi perubahan terhadap lingkungan dan ketersediaan makanan diperkirakan nilai ini juga akan berubah. Variasi nilai ini dapat disebabkan oleh berbagai faktor, seperti jumlah rajungan contoh yang diukur, kondisi perairan dan musim (Afifah, 2017).

Pada penelitian ini didapatkan bahwa sex rasio antara betina dan jantan adalah 1,06:1. Jumlah rajungan betina lebih banyak daripada rajungan jantan. Hasil yang didapat dari penelitian ini juga sama dengan penelitian Sunarto (2012) yang menyatakan bahwa Hampir sepanjang tahun rajungan betina memiliki persentase lebih tinggi dibandingkan rajungan jantan. Hanya pada bulan April, Mei dan Juni persentase rajungan jantan relatif lebih tinggi dibandingkan rajungan betina. Data ini dapat memperkuat pernyataan bahwa rajungan jantan mampu membuahi lebih dari satu rajungan betina. Diperkirakan pada bulan-bulan tersebut tengah terjadi pemijahan sehingga rajungan betina berada pada daerah yang lebih dalam atau jauh dari pantai.

Tidak seimbangnya antara jenis kelamin betina dan jantan terjadi karena pola hidup yang dipengaruhi oleh makanan yang tersedia, kepadatan populasi, dan keseimbangan makanan. Perbandingan nisbah kelamin di alam tidak akan mutlak dan dapat dipengaruhi oleh ketersediaan makanan, keseimbangan rantai makanan dan kepadatan populasi. (Effendie, 2002). Proporsi yang tidak seimbang, dengan rajungan betina yang lebih dominan menunjukkan perlunya kehati-hatian terhadap penangkapan rajungan khususnya rajungan betina karena proses penambahan baru dapat terhambat disebabkan menurunnya populasi rajungan betina (Tirtadanu, 2017).

Peraturan Menteri Kelautan Republik Indonesia Nomor 1/PERMEN-KP/2015 tentang Tentang Penangkapan Lobster (Panulirus spp.), Kepiting (Scylla spp.), dan Rajungan (Portunus pelagicus spp.) menyebutkan mengenai larangan penangkapan rajungan yang memiliki lebar karapas dibawah $10 \mathrm{~cm}$. Berdasarkan pada peraturan ini terdapat $37 \%$ rajungan baik jantan dan betina dibawah $10 \mathrm{~cm}$ dari keseluruhan hasil tangkapan Penangkpaan rajungan dengan ukuran dibawah $10 \mathrm{~cm}$ berarti tidak mendukung pengelolaan perikanan yang berkelanjutan karena menghambat/mengurangi rekrutmen stok pada suatu perairan. Sehingga diperlukan kebijakan yang dikhususkan bagi penangkapan rajungan di perairan Jepara agar berkelanjutan. Terdapat beberapa faktor lingkungan yang diamati selama penelitian, yakni suhu, salinitas, DO (oksigen terlarut), dan $\mathrm{pH}$. Suhu pada lokasi penangkapan berkisar $28{ }^{\circ} \mathrm{C}-28,06{ }^{\circ} \mathrm{C}$, hasil ini lebih rendah jika dibandingkan dengan perairan Pati dengan kisaran suhu $27,5^{\circ} \mathrm{C}-31,5^{\circ} \mathrm{C}$ (Ernawati, 2013). Dari hasil ini diketahui bahwa suhu perairan Jepara masih tergolong kedalam kisaran suhu yang mendukung kehidupan rajungan, yakni $17-30{ }^{\circ} \mathrm{C}$ (KKP, 2015).

Salinitas pada setiap lokasi penangkapan berkisar antara 30,33\%o-30,66\%. Hasil ini lebih rendah jika dibandingkan perairan Brebes yang memiliki salinitas pada kisaran 30\%o - 33\%o (Santoso, 2016). Hasil pengamatan menunjukkan bahwa perairan Jepara memiliki salinitas yang ideal untuk mendukung pertumbuhan rajungan. Menurut Chande dan Mgaya (2003) salinitas yang ideal untuk pertumbuhan rajungan adalah 27 - 32 \%. Rajungan dapat mengatur kondisi osmotik di dalam tubuhnya yang hiposalin terhadap kondisi air laut yang hipersalin agar tetap sesuai dengan lingkungannya, sehingga rajungan dapat hidup pada kisaran salinitas yang luas (11-53\%o untuk waktu lama (Kangas, 2000). Kadar oksigen terlarut di dalam massa air nilainya adalah relatif, biasanya berkisar antara 6-14 mg/l (Connel et al., 1995). Berdasarkan hasil pengamatan Oksigen 

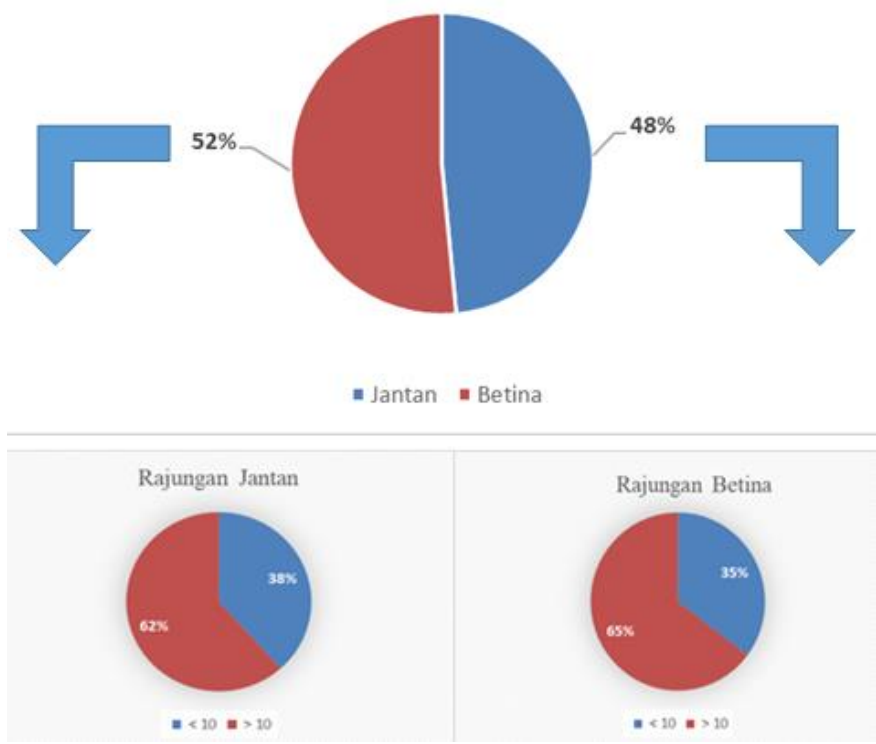

Gambar 5. Presentase rajungan jantan dan betina selama penelitian di Jobokuto, Jepara

Tabel 4. Hasil sampling pengukuran parameter lingkungan perairan Jepara

\begin{tabular}{ccccc}
\hline Pengulangan & Stasiun 1 & Suhu & Salinitas & DO \\
\hline 1 & $\mathrm{~S} \mathrm{O6}^{\circ} 34^{\prime} 34.2^{\prime \prime}$ & 28,1 & 30 & 2,87 \\
2 & $\mathrm{E} 110^{\circ} 38^{\prime} 40.4^{\prime \prime}$ & 28,1 & 30 & 2,94 \\
3 & (Dekat) & 28 & 31 & 2,97 \\
Rata-rata & & 28,06 & 30,33 & 2,92 \\
\hline Pengulangan & Stasiun 2 & Suhu & Salinitas & DO \\
\hline 1 & $\mathrm{~S} \mathrm{O6}^{\circ} 34^{\prime} 41.7^{\prime \prime}$ & 28 & 31 & 2,6 \\
2 & $\mathrm{E} 110^{\circ} 38^{\prime} 47.6^{\prime \prime}$ & 28,1 & 31 & 2,68 \\
3 & (Jauh) & 28,1 & 30 & 2,78 \\
Rata-rata & & 28,06 & 30,66 & 2,68 \\
\hline
\end{tabular}

terlarut (DO) perairan Jepara berkisar antara 2,6-2,9 mg/l, bila mengacu pada kriteria kualitas air, perairan Jepara memiliki DO yang kurang ideal untuk pertumbuhan rajungan karena termasuk pada kriteria tercemar sedang (Tabel 4). Namun pada kondisi seperti ini rajungan masih bisa beradaptasi dengan habitatnya. Hal ini diperkuat oleh Dhawan et al. (1976) yang menyatakan rajungan masih bertahan hidup di estuari dengan kondisi oksigen terlarut $<2 \mathrm{mg} / \mathrm{l}$.

\section{KESIMPULAN}

Distribusi lebar karapas rajungan dari perairan Jepara adalah berkisar antara 6,0 cm - 16,7 $\mathrm{cm}$ dan kisaran berat sebesar 15 gram - 375 gram. Pola pertumbuhan rajungan yang ada di perairan Jepara adalah allometrik negatif, dengan nilai b sebesar 1,68 untuk rajungan jantan, 2,80 untuk rajungan betina. Presentase rajungan betina yang tertangkap adalah $52 \%$, sedangkan presentase rajungan jantan yang tertangkap adalah $48 \%$. Rajungan yang tertangkap terdiri dari $63 \%$ berukuran $>10 \mathrm{~cm}$, dan $37 \%$ berukuran $<10 \mathrm{~cm}$.

\section{DAFTAR PUSTAKA}

Afifah, N. 2017. Morfometri dan Sebaran Ukuran Rajungan (Portunus pelagicus, Linnaeus 1758) di Perairan Pulau Lancang, Kepulauan Seribu. Bogor : Institut Pertanian Bogor. 
Apriliyanto, H. \& Yulianto, T., 2014. Analisis Daerah Penangkapan Rajungan Dengan Jaring Insang Dasar (Bottom Gillnet) Di Perairan Betahwalang, Demak. Journal of Fisheries Resources Utilization Management and Technology, 3(3):71-79.

Asnidar, S. 2013. Kajian Stok Rajungan (Portunus pelagicus) Berdasarkan Hubungan Lebar Berat dan Mortalitas pada Tempat Pendaratan Ikan di Desa Kawal Kabupaten Bintan. Tanjung Pinang : FIKP UMRAH.

Budiaryani N.R. 2007. Kajian Perikanan Rajungan di Perairan Semarang. Semarang (ID): BBPPI.

Chande, A.I. \& Mgaya, Y.D., 2003. The fishery of Portunus pelagicus and species diversity of portunid crabs along the Coast of Dar es Salaam, Tanzania. Western Indian Ocean Journal of Marine Science, 2(1):75-84.

Connel, W.D. \& Miller, G.J. 1995. Kimia dan Ekotoksikologi Pencemaran. Terjemahan. Penerbit Universitas Indonesia: 520 hal.

Dhawan, R.M., Dwivedi, S.N. \& Rajamanickam GV. 1976. Ecology of the blue crab Portunus pelagicus (Linnaeus) and its potential fishery in Zuari estuary. Indian Journal Fisheries, 23(12):57-64.

Effendie MI. 2002. Biologi Perikanan. Yogyakarta (ID): Yayasan Pustaka Nusatama.

Ernawati T. 2013. Dinamika populasi dan pengkajian stok sumber daya rajungan (Portunus pelagicus) diperairan Kabupaten Pati dan sekitarnya. [Tesis]. Bogor (ID): Institut Pertanian Bogor.

Jaya, I. \& Sondita, M.F.A., 2012. Model bioekonomi perairan pantai (in-shore) dan lepas pantai (off-Shore) untuk pengelolaan perikanan rajungan (Portunus pelagicus) di Perairan Selat Makassar. Jurnal IImu-IImu Perairan dan Perikanan Indonesia, 13(1):33-43.

Kangas, M.I. 2000. Synopsis of the biology and exploitation of the blue swimmer crab, Portunus pelagicus Linnaeus, in Western Australia. Fisheries Research Report Fisheries Western Australia. 121:1-22.

Kementerian Kelautan dan Perikanan [KKP]. 2015. Peraturan Menteri Nomor 1/PERMENKP/Tahun 2015 tentang Penangkapan Lobster (Panulirus spp.), Kepiting (Scylla spp.) dan Rajungan (Portunus pelagicus spp.)

Kurnia, R., Boer, M. \& Zairion. 2014. Biologi populasi rajungan (Portunus pelagicus) dan karakteristik lingkungan habitat esensialnya sebagai upaya awal perlindungan di Lampung Timur. Jurnal Ilmu Pertanian Indonesia, 19(1):22-28.

Prihatiningsih, P. \& Wagiyo, K. 2009. Sumber daya rajungan (Portunus pelagicus) di Perairan Tangerang. Bawal. 2 (6):273-282.

Santoso, D., Karnan, Japa, L. \& Raksun, A., 2016. Karakteristik Bioekologi Rajungan (Portunus Pelagicus) Di Perairan Dusun Ujung Lombok Timur. Jurnal Biologi Tropis, 16(2):94-105

Sparre, P. \& Venema, S.C., 1999. Introduksi pengkajian stok ikan tropis, Buku I: Manual. Widodo J, Meta IGS, Nurhakim S, Baharudin M. Jakarta: Pusat Penelitian dan Pengembangan Perikanan. Terjemahan dari Introduction to Tropical Fish Stock Assassment. Part I: Manual. Jakarta (ID): FAO.

Sumiono, B. 2011. Aspek penangkapan dan biologi rajungan (Portunus pelagicus) di perairan Teluk Jakarta. Bogor: PT Penerbit IPB Press.

Sunarto. 2012. Karakteristik Bioekologi Rajungan (Portunus pelagicus) di Perairan Laut Kabupaten Brebes. Bogor : Institut Pertanian Bogor.

Tirtadanu, T. \& Suman, A. 2017. Aspek Biologi, Dinamika Populasi, dan Tingkat Pemanfaatan Rajungan (Portunus pelagicus Linnaeus, 1758), di Perairan Kota Baru, Kalimantan Selatan. Jurnal Penelitian Perikanan Indonesia, 23(3):205-214.

Ubaidillah, F. 2014. Perbedaaan Lama Penarikan dan Hasil Tangkapan pada Pengoperasian Bubu Rajungan (Portunus sp.) dengan Rancang Bangun Alat Penarik Tali Utama di Desa Betahwalang Kabupaten Demak. Journal of Fisheries Resources Utilization Management and Technology, 3(2):1-8. 